\title{
ボード内高速光伝送技術（ポリマー光導波路）
}

\author{
荒井 進也*
}

\section{On-Board High Speed Optical Transmission Technology (Polymer Waveguide)}

\author{
Shinya ARAI*
}

*住友ベークライト株式会社光電気複合インタポーザ事業開発推進部（１ 140-0002＼cjkstart東京都品川区東品川二丁目 5 番 8 号）

*COIN Business Development Dept., SUMITOMO BAKELITE CO., LTD (2-5-8, Higashi- Shinagawa, Shinagawa-ku, Tokyo 140-0002)

\section{1.はじめに}

近年, スーパーコンピュータやデータセンタの高性能化 は著しい。データ保存や計算リソースをネットワーク経由 で利用する, いわゆるクラウド化によりデータセンタで取 扱う情報量は飛躍の一途を辿る。例えば富士通のスーパー コンピュータ PRIMEHPC FX100 では 1 レーン当たりの伝 送速度は25.78125 Gbps であり, 光伝送比率が電気伝送の 比率を大きく上回るとの報告もされている ${ }^{1)}$ 。

現在普及する光配線は, ラック間接続をする光トラン シーバやアクティブ光ケーブル (Active Optical Cable, AOC) に用いられる光ファイバであるが, 近年データセンタのハ イパースケール化に伴い, QSFP28 以降のメーカ間合意規 格活動として, ボード内光インターコネクションに関する 標準化推進も COBO (Consortium for On-Board Optics) ${ }^{2)}$ など の活動に代表される様に機運が高まり, ボード内領域の光 配線化が進んでいる。

現状, これらの光配線は石英光ファイバをベースとして おり, 光コネクタや光モジュールの接続信頼性, 並びに光 モジュールの発熱など光インターコネクションに関する課 題と改善策が多く報告されている ${ }^{3), 4)}$ 。本項では, 今後さら に高集積化が予測されるボード内の光配線課題について, その解決手段として期待されるポリマー光導波路 (Polymer Waveguide, PWG) の採用利点, 性能目標值, 現状課題と改 善技術を順に紹介する。

\section{2. ポリマー光導波路を用いた高速光信号伝送}

\section{1 サーバラック内の光導波路配線領域}

現状，サーバラック内で光配線の採用検討が行われてい る領域を図 1 に示す。光伝送距離は LSI などのチップ間を 結ぶ MCM 上の数 $\mathrm{mm}$ から, チップとボードエッジを接続 する数十 $\mathrm{cm}$ 程度, 最大長ではボード間接続を想定した $1 \mathrm{~m}$ までの領域が適用範囲にあると考えられている。光電変換 モジュールは電気伝送距離を極力短くするために, LSI 近 傍に配置する検討をされる事が多く, 本項では解説を割愛

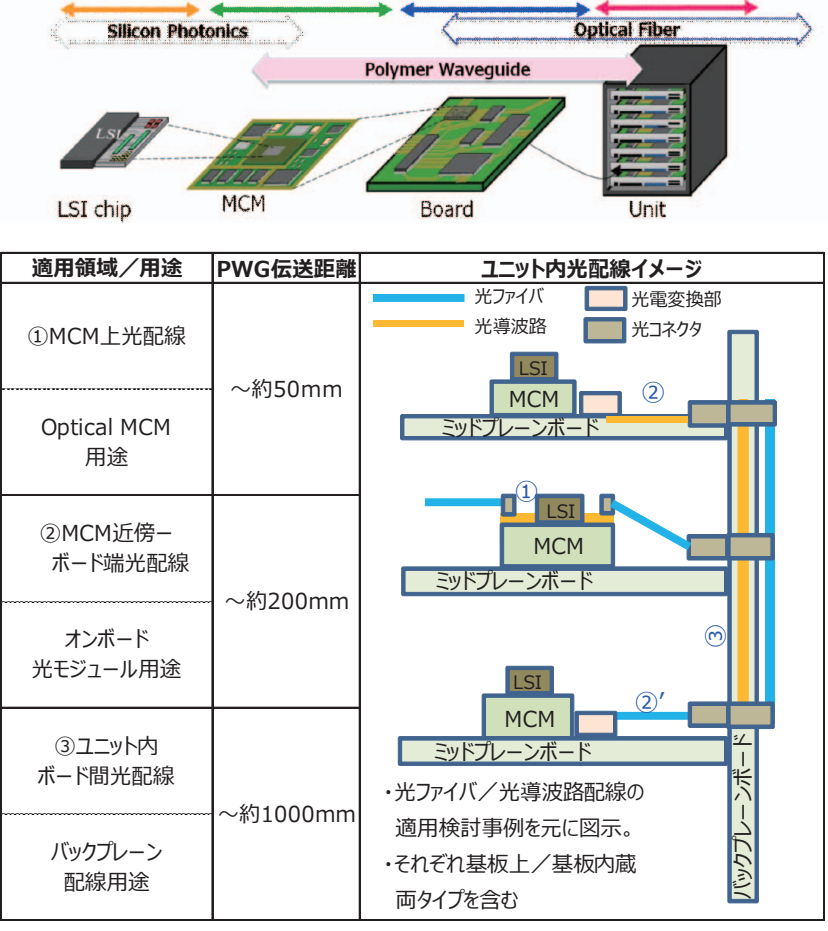

図 1. サーバーボード内の PWG ・光ファイバ適用領域と光 配線距離

しているが, 光ファイバを主としたオンボード光モジュー ルでは図 1 の(2) に示す領域での開発がその主流である。

\section{2 ポリマー光導波路の利点}

PWG はポリマーの特長である柔軟性により，ボード上の 実装部品が密集する領域を回避する配線が出来る。また, プリント配線板へ直接光回路を形成する使い方や, 一度 フィルム化した光配線を後から電気基板に貼り合わせるな ど光電気複合基板としての使い方も可能である。また，光 回路の特長としては, 光ファイバのように並走する多芯配 線に加えて, 同一面層内において, 湾曲配線, 多分岐配 線，クロス配線などが製法上容易に形成できる。また多芯 配線についても, 光回路間ピッチ $100 \mu \mathrm{m}$ を下回る様な高 密度配線が可能である。 
基本的には光源, および光ファイバと相互接続して使用 されることを前提としており, 前述する特長から MCM お よび基板上，または基板内蔵配線など光ファイバでは引き 回し困難な領域を補完することが期待されている5 。

\section{3 ポリマー光導波路の種類と特性}

PWG は光ファイバ同様にシングルモード (SM) とマルチ モード (MM) 導波路の 2 種類に大別されるが，ここでは多 芯伝送を前提とする MM に限定して解説を行う。

MM を細分化すると，コア内の屈折率分布が一様である ステップインデックス (SI) 型と屈折率分布が緩やかに変化 するグレーデッドインデックス (GI) 型に分類される（図 2)。SI 型はコア部とクラッド部で屈折率が異なるため, そ の境界面にて全反射伝送する方式である。その特性から光 信号のモード分散が大きく, 伝送带域も狭くなる傾向にあ る。

一方, GI 型は光伝搬速度が屈折率に反比例する特性を利 用することで, 経路の異なるモードの伝送路出力端への到 達時間を近づける事ができる。このため, SI 型と比較して 光伝送の高速化や長距離伝送に有効とされている。尚, 図 2 に記載する散乱損失やクロストークについても，この屈 折率構造の違いにより生じるがこの課題については後述す る。

一般的に PWG を作製する際は，フォトリソグラフィな どプリント配線板と同様の製法でコア部形成後に周囲のク ラッドを形成する工法が用いられており, SI 型構造が現在
の主流である。

\section{3. ポリマー光導波路の光伝送性能目標値と技術課題, 開発動向}

\section{1 光伝送性能の目標値}

まず初めに，ポリマー光導波路の伝送性能目標值につい て紹介する。表 1 は目標とする伝送レート（単位：Gbps） について, 伝送距離毎に必要な伝搬損失 (Propagation loss) (単位 : $\mathrm{dB} / \mathrm{cm}$ ) とモーダル帯域幅 (Modal Bandwidth, MBW) （単位： $\mathrm{GHz} \cdot \mathrm{m}$ ）を示したものであり，双方の性能を同時 に達成することで伝送が可能となる。尚, 表 1 の目標值を 算出する前提としていくつか仮定をおいている。ひとつは 光変調振幅基準の相対強度雑音 (RIN_OMA) であり，-130 $\mathrm{dB} / \mathrm{Hz}(25 \mathrm{Gbps}),-135 \mathrm{~dB} / \mathrm{Hz}(56 \mathrm{Gbps})$ としている。目標 仕様の算出の詳細については, JIEP 光回路実装技術研究会 発行「光回路実装ロードマップ 2016 年度版」を参照戴きた (7)。

この目標仕様案から, 例えば $56 \mathrm{Gbps}$ の速度で $100 \mathrm{~cm}$ の 伝送路の実現を目指す場合，伝搬損失 $0.04 \mathrm{~dB} / \mathrm{cm}, \quad M B W$ $60 \mathrm{GHz} \cdot \mathrm{m}$ の達成がひとつの目安といった見方が出来る。

\section{2 ポリマー光導波路における伝送性能課題}

光ファイバ伝送に扔いては, マルチモード光ファイバ自 体が既に成熟した技術，製法であるため，光伝搬損失や MBW は少なくとも本項で議論される配線長においては議 論の対象とならない。一方，ポリマー光導波路については

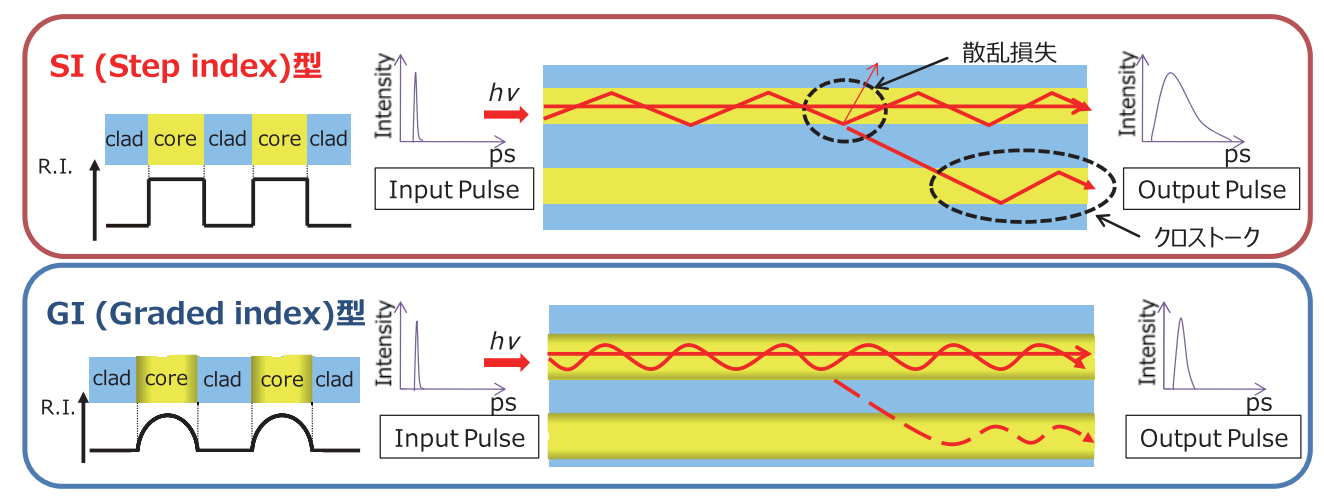

図 2. SI 型と GI 型の屈折率分布・モード分散の違い

表 1.マルチモードポリマー光導波路の目標仕様案

\begin{tabular}{|c|c|c|c|c|c|c|}
\hline \multicolumn{2}{|r|}{ 項 目 } & 単位 & $\begin{array}{c}\text { VSR } \\
\text { (Chip to Mod.) } \\
10 \mathrm{~cm}\end{array}$ & $\begin{array}{c}\text { SR } \\
\text { (Chip to Mod.) } \\
30 \mathrm{~cm}\end{array}$ & $\begin{array}{c}\text { MR } \\
\text { (Chip to Mod.) } \\
50 \mathrm{~cm}\end{array}$ & $\begin{array}{c}\text { LR } \\
\text { (Back plane) } \\
100 \mathrm{~cm}\end{array}$ \\
\hline \multirow{3}{*}{$\begin{array}{l}\text { 現状 } \\
\text { (SI 型) }\end{array}$} & RIN_OMA & $\mathrm{dB} / \mathrm{Hz}$ & \multicolumn{4}{|c|}{-130} \\
\hline & Propagation Loss & $\mathrm{dB} / \mathrm{cm}$ & \multicolumn{4}{|c|}{ 0.05@850nm, 0.15@1,060 nm, 0.20@1,310 nm } \\
\hline & Modal Bandwidth & $\mathrm{GHz} \cdot \mathrm{m}$ & \multicolumn{4}{|c|}{8} \\
\hline \multirow{3}{*}{$\begin{array}{l}\text { 目標 } 1 \\
25 \mathrm{Gbps}\end{array}$} & RIN_OMA & $\mathrm{dB} / \mathrm{Hz}$ & \multicolumn{4}{|c|}{-130} \\
\hline & Propagation Loss & $\mathrm{dB} / \mathrm{cm}$ & 0.4 & 0.12 & 0.08 & 0.04 \\
\hline & Modal Bandwidth & $\mathrm{GHz} \cdot \mathrm{m}$ & 8 & 8 & 30 & 30 \\
\hline \multirow{3}{*}{$\begin{array}{l}\text { 目標 } 2 \\
50 \mathrm{Gbps}\end{array}$} & RIN_OMA & $\mathrm{dB} / \mathrm{Hz}$ & \multicolumn{4}{|c|}{-135} \\
\hline & Propagation Loss & $\mathrm{dB} / \mathrm{cm}$ & 0.4 & 0.15 & 0.09 & 0.04 \\
\hline & Modal Bandwidth & $\mathrm{GHz} \cdot \mathrm{m}$ & 8 & 30 & 60 & 60 \\
\hline
\end{tabular}


下記の様な課題が挙げられる。

\section{2 .1 光結合損失}

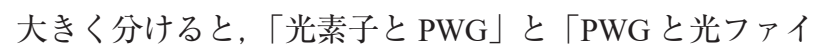
バ」の 2 箇所の接続損失が考えられる。とりわけ後者はSI 型と GI 型との接続によりコア径の違いや開口数 (Numerical Aperture, NA) の差によるミスマッチが発生する上に, 異な る形状, 材料同士の光接続になるため, 界面での反射損失 やチャネル間損失バラつきなども増加する傾向にある。こ れらは, 光接続部におけるパターン幅の適正化やスポット サイズ変換 (Spot-Size Converter, SSC) の採用, 光コネクタ への集光機能付与などが改善策として挙げられる。また, 反射損失，チャネル間バラつきの抑制にはマッチング部材 などの採用などが効果的である。

\section{2 .2 光伝搬損失}

光伝搬損失に関しては, 不純物混入やボイド, コア表面 荒れなど製造に依存する外的要因と, 材料自身が持つ吸 収, 散乱損失など内的要因とに分けられる。とりわけSI 型 に扔いては, 屈折率境界面の仕上がりが伝搬性能の優劣に 直結する。ただし図 2 のように GI 型のような屈折率分布 を有する場合は, 緩やかな屈折率変化により光が閉じ込め られるため, 散乱損失を抑制することに一定の効果が見込 める。

吸収損失は主に電子遷移吸収と分子振動吸収があり, そ れぞれ光源の波長带により影響度合いが変わるため, 使用 する波長に応じた材料チューニングが行われていることが 多い。PWGに打いては，1,000 nm を越える長波長域にお ける炭素一水素 $(\mathrm{C}-\mathrm{H})$ 結合による吸収影響が顕著なため, 改善手段として水素の一部を重水素, またはフッ素置換し て吸収波長をシフトすることで同波長带域における吸収損 失を低隇する方式が提案されている ${ }^{8)}$

\subsection{3 光伝搬遅延}

信号速度の高速化や光路の長さに比例して発生する。光 の伝搬は，伝送路内を伝搬する経路，入射角度などにより 幾つかのモードに分かれて扔り，入射角が小さいものから 0 次, 1 次， $\cdots, \mathrm{N}$ 次モードと表され入射角が大きい程, 遅 延が大きくなる。光伝送は位相ずれにより干渉抒よび消滅 するため, MM 伝送方式に限り带域幅について議論される ことになる。

表 1 の現状值に示される通り, SI 型光導波路の MBW は 抢よそ $8 \mathrm{GHz} \cdot \mathrm{m}$ に留まるが, 現在主に議論される $25 \mathrm{Gbps}$ 以上の伝送速度に扔いては $30 \mathrm{~cm}$ を越える領域で性能不足 に陥ると考えられる。

\subsection{4 光クロストーク}

電気信号同様に周辺配線への混信度合を指し, 配線の並 走距離が長く, 配線間の距離が近いほど影響が強くなると されている。しかしながら， MM 光ファイバにおいては 1 本毎に被覆がされているため, そもそも同課題が取り上げ られることは少ない。一方で, PWGに扔いては, 採用され
る可能性がある配線長について考察した場合，並走する伝 送路長こそ最大でも $1 \mathrm{~m}$ と短いものの, 各コアの間は屈折 率の異なるクラッド層で遮られるのみである。そのため, 一度コアから漏れ出た光はクラッド層を直進し，隣接する コアやさらには隣接コアを通り抜けた先のコアにまで伝搬 し，各コア内を伝搬する別の光信号に混信することが報告 されている ${ }^{9}$ 。屈折率分布構造を最適化することや，屈折 率境界面の荒れの改善, または, 伝送路が持つ屈折率を越 えないNA の制御などが解決手段として挙げられている。

\section{$3.3 \mathrm{GI}$ 型光導波路における伝送性能改善効果}

上記で挙げた伝送性能の目標值や想定される課題に対し て, 性能改善に大きく寄与する技術として, 2.3 項で言及し た GI 型構造の採用が挙げられる。現在, 大学や研究機関, メーカ各社からいくつかの報告 ${ }^{10,11)}$ がされている。課題毎 に紹介していく。

\subsection{1 光結合効率改善}

1 点目の報告 ${ }^{12)}$ では, コアを覆う上下および左右全周囲 のクラッドに対して GI 屈折率分布を形成する光導波路製 法と性能についてである。コア径 $\square 45 \mu \mathrm{m}$, 伝送路長 66.5 $\mathrm{mm}$ の PWG の両端に GI 型ファイバ（コア径 $\phi 50 \mu \mathrm{m}$ ）を接 続した際に, 伝搬損失を含み損失が約 $0.6 \mathrm{~dB}$ と SI 型と比 較して良好な結果が得られている。また，コア位置ズレに よる結合損失も $1 \mathrm{~dB}$ 増加に対して約 $\pm 10 \mu \mathrm{m}$ のトレランス が得られている。

\subsection{2 光伝搬遅延改善}

2 点目の報告 ${ }^{13)}$ では, クラッド部を形成した後に特殊な 熱処理を加えることにより，コアとクラッドの境界部に材 料の屈折率分散を発現させることで, GI 型に近い屈折率分 布を実現している。この結果, MBW は $1.0 \mathrm{~m}$ 長のスパイ ラルパターンの PWG に扔いて $60 \mathrm{GHz} \cdot \mathrm{m}$ 以上の性能を達 成している。

\subsection{3 クロストーク改善}

3 点目の報告 ${ }^{14)}$ では GI 型と SI 型の各光導波路における 併設するコアとのクロストーク改善効果を示している。配 線間ピッチ $250 \mu \mathrm{m}$ で配置された隣接コアに対しても -40 $\mathrm{dB}$ 以上と非常に安定したクロストーク性能が得られてい る。

\section{4. 終わりに}

以上，ボード内光配線に扔ける光配線長，および光伝送 路であるポリマー光導波路の課題として，伝送損失（結合 損失, 伝搬損失), 伝搬遅延, クロストークの 3 つに触れ, その要因と開発状況について紹介した。今後のマルチモー ドポリマー光導波路の開発指針，あるいは光導波路を採用 検討される方の一助となれば幸いである。

(2017.6.6- 受理) 


\section{文献}

1) http://www.fujitsu.com/downloads/JP/archive/imgjp/jhpc/ primehpc/primehpc-fx100-hard-ja.pdf

2) http://cobo.azurewebsites.net/

3) R. Joshua, et al.: "Extended temperature performance of $120 \mathrm{Gbps}$ midboard optical engine," Proc. of SPIE, Vol. 9753, 97530E-1

4) T. Uemura, et al.: "Thermal design of $28-\mathrm{Gb} / \mathrm{s} \times 24$-channel CDR-integrated VCSEL-based transceiver module," ICSJ2016, pp. $79-82$

5) https://annex.jsap.or.jp/photonics/kogaku/public/37-02sougouhoukoku.pdf

6) http://kikakurui.com/c5/C5954-3-2013-01.html 7.10. 相対強 度雑音

7) 光回路実装技術委員会 光回路実装技術研究会：光回路実装 ロードマップ 2016 年度版 “光インターコネクションの第二 普及世代に向けた課題と予測, ” pp. 61-71, Feb. 2017

8) http://www.hitachi-chem.co.jp/japanese/report/048/48_r3.pdf

9) https://www.jstage.jst.go.jp/article/ejisso/24/0/24_264/_pdf

10) B. W. Swatowki, C. M. Amb, M. G. Hyer, R. S. John, and W. K. Weidner: "Graded index silicon waveguides for high performance computing," OIC2014, pp. 133-134

11) K. Soma and K. Ishigure: "Fabrication of a graded-index circularcore polymer parallel optical waveguide using a micro dispenser for a high density optical printed circuit board," IEEE J. Sel. Top. Quantum Electron., Vol. 19, No. 2, 3600310, 2013

12) A. Horimoto, et al., Sumitomo Bakelite: "Simple Channel Reconnection using Polynorbornene Based GI Waveguide for Optical Interconnect," ICSJ2015, pp. 118-121

13) N. Bamiedakis, et al., University of Cambridge: "High-bandwidth and low-loss multimode polymer waveguides and waveguide components for high-speed board-level optical interconnects," SPIE2016, Vol. 9753, 975304-1-9

14) R. Kinoshita, et al.: "Polymer Optical Waveguides With GI and W-Shaped cores for High-Bandwidth-Density On-Board Interconnects," JOUNAL OF LIGHTWAVE TECHOLOGY, Vol. 31, No. 24, DECEMBER 15, 2013

荒井進也（あらい しんや）

住友ベークライト株式会社

光電気複合インタポーザ事業開発推進部 